Copyright (C) 2016 by Academic Publishing House Researcher

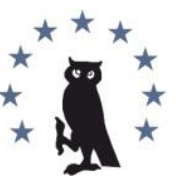

Published in the Russian Federation

European Researcher

Has been issued since 2010.

ISSN 2219-8229

E-ISSN 2224-0136

Vol. 103, Is. 2, pp. 87-106, 2016

DOI: 10.13187/er.2016.103.87

www.erjournal.ru

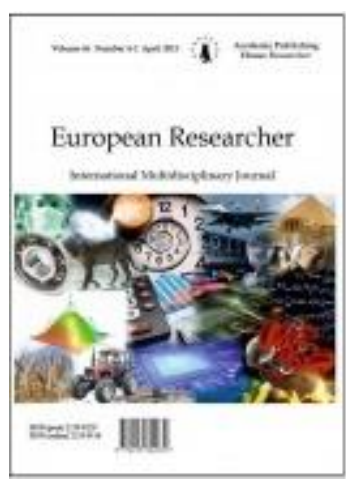

UDC 33

\title{
Comparative Analysis of Conditions Life in Settlements the Municipality of Berane and Settlements the Municipality of Andrijevica: A Case Study
}

\author{
${ }^{1}$ Goran Rajović \\ ${ }^{2}$ Jelisavka Bulatović
}

\author{
${ }^{1-2}$ International Network Center for Fundamental and Applied Research, Russian Federation \& \\ Academic Member ATINER based on Serbia, Serbia \\ Dr \\ E-mail: dkgoran.rajovic@gmail.com \\ ${ }^{2}$ College of Textile Design, Technology and Management, Serbia \\ Street Starine Novaka 24, Belgrade \\ MSc \\ E-mail: jelisavka.bulatovic@gmail.com
}

"How much has of that, what us not necessary "Socrates

(Diogenész, 2005).

\section{Abstract}

The focus of work is the conception quality of life issues that in lately, it becomes increasingly important socio-economic issue. The work tends to argue how and which the context of the quality of rural life provides an opportunity to resolve the paradox of development interpreted by many researchers. The study was designed and conducted in the geographical and social space, as a case study. Geographic space research included is urban settlements: Berane and Andrijevica as well as the rural: Dolac, Lužac, Dapsiće, Luge, Polica, Gnjili Potok, Kralje, Slatina, Zabrđe and Rijeka Marsenić. Social space related to the surveyed residents of what is meant, and our insight into the social environment. The existence of differences in living conditions, opportunities and attitudes of urban and rural residents has been formulated as a null hypothesis in the study. The aim of the research is that the comparative view of living and working conditions of rural and urban population and comparative data analysis tested the validity of the initial assumptions. The analysis includes the following dependent variable: level of education, occupation, housing conditions, health status, satisfaction of patients through life and the rank the reasons for the concern of respondents living in town is an independent variable. research.

Keywords: living conditions, rural, urban, municipality Berane, municipality Andrijevica,

\section{Introduction}

Although we will not deal with nor philosophical neither originating nor historiography term, according to Ilić et al (2010) (citing research Vittersø, 2004 and Butow, 2009) discussion about the quality of life dates back to Plato and Aristotle. As an academic discipline in the quality of life 
appeared in 1970 and was confirmed in 1974 and considered by the scientific journal "Social Indicators Research". The second important academic publications multidisciplinary "Journal of Happiness Studies", multidisciplinary journal that allows discussion on what are the two main starting points for the study of happiness, namely: theoretical essays good life and empirical research on subjective well-being. International Association for Research Quality of life (ISQOLS) serves as a forum for academic researchers working in this field, encouraging interdisciplinary research, methodological discussions and development. Searching the database by Ilic et al (2010) for the period from 1974 to 2008, found is that the quality of life in the year 1974 mentions only in 8 publications, in the year 1984 in 284, in 1994 in 1.209, in 2003 in 3.519, in 2008 in 66.592 scientific articles. Quality of life is treated as a central theme in 1974 in a scientific article 2, in 1984 in 93, in 1994 in 502, in 2003 in 1.060 and 2008 in 20.355.

Milivojević et al (2012) asks himself what the essence of satisfaction with their own lives and what are the key aspects? Is it the same for everyone and is a function of his age and his status in society? How to him affect the value systems and cultures of human communities? In the knowledge society more and more people want to work home while maintaining a career and raising children. Quality of performance is becoming more important than quantity. Old and young, men and women, all want to live healthier with a peaceful and spiritually fulfilling life. All they want highly ethical society in which they can trust, and that is not based on exploitation but on helping each other, which gives a real base to realize their hopes and dreams. People want to be happy throughout your life. This all suggests that there has been a significant change in key aspects of satisfaction with their lives.

From more practical point of view, the conception of the quality of life can be seen as the reaction of the modern society to the problems it has to deal with. Due to this statement we will conclude the paper with the specification of some possibilities of the practical utilization of the knowledge acquired via the geographical quality of life research (Andraško, 2009). Combining the conclusions of Pacione (2003), Andraško (2005), Andraško (2006) and Andráško (2007) these include: production of the spatial projection of the information regarding the quality of life in particular areas; assessment of the spatial differentiation of selected territory from the quality of life viewpoint; production of territorial comparisons of the levels of quality of life and identification of the most "problematic" areas; production of visually transparent outputs (mainly maps), representing the information regarding the quality of life in quite simple and comprehensible, user friendly manner; creation of the specialized Geographical Information Systems as an highly operative tool for handling the quality of life related data; production of some baseline measures of quality of life against which we can compare subsequent measures and identify trends over time; knowledge of how satisfactions and dissatisfactions are distributed through society and across space; understanding the structure and dependence or interrelationship of various life concerns; understanding how people combine their feelings about individual life concerns into an overall evaluation of quality of life; achieving a better understanding of the causes and conditions which lead to individuals' feelings of well-being, and of the effects of such feelings on their behavior; identifying problems meriting special attention and possible societal action; identification of normative standards against which actual conditions may be judged in order to inform effective policy formulation; monitoring the effects of policies on the ground and promoting public participation in the policy making (Andraško, 2009).

In order to understand the changes of the concept of quality of life, it is necessary to know the essence of life and its interaction with the social order, and with the physical environment. With the right Bohnke (2005) concludes that the improvement of the primary goal of European social policy: happy, satisfied and engaged citizens contribute to the booming of European society. In light of EU enlargement, the interest in living conditions in different European countries. Subjective well-being of the population is one of the many aspects that need to be explored in this context.

\section{Research methodology}

The study was designed and conducted in the geographical and social space, as a case study. Geographic space research included settlements municipalities Berane (urban settlement Berane iand rural: Dolac, Lužac, Dapsiće, Luge and Polica) and settlement municipalities Andrijevica (urban settlement Andrijevica and rural: Gnjili Potok, Kralje, Slatina, Zabrđe and Rijeka Marsenić). Social space related to the surveyed residents of what is meant, and our insight into the social 
environment. Your chosen settlements municipalities Berane and municipalities Andrijevica are different in relation to the demographic structure of the population, population density, physiognomic characteristics and position within the structure of urban and rural settlements northeastern of Montenegro (see Rajović and Bulatović, 2012; Rajović and Bulatović, 2013; Rajović and Bulatović, 2013; Rajović and Bulatović, 2013; Rajović and Bulatović, 2015; Rajović and Bulatović, 2015; Rajović and Bulatović, 2016). Population survey is conducted on three occasions, in late July 2012, the beginning of August 2013 and mid-August 2014. In order to obtain representative data is planned to include 112 survey respondents. Since, on the initial assumption that the social characteristics of the subjects affect their grades and attitudes, and bearing in mind the research authors of this text Rajović and Bulatović (2015) planning sample survey was applied multi-phased sample in combination accidental and deliberate selection of respondents, in order to ensure the quota. The planned number of surveyed residents in the implementation of the survey is been exceeded, but the stricter control logic questionnaires at the end of processed a total of 91, which represents a very high in realization $81.3 \%$ of the planned sample. In the second stage of research were selected respondents in rural settlements in the city of municipalities Berane and municipalities Andrijevica combined accidental and deliberate choice. In the third stage of the research were determined quota of respondents by gender and age. The range covered by the ages of 18 to 60 years or more. Sam methodological procedure is based on research Kajari and Šandor (2011), that was based on an analysis of the frequency and the analysis of dependence, which is determined using the so-called Tschuprow's association coefficient of interdependence, so that the views and opinions of respondents analyzed by the method of ranking and comparing the obtained rank Spearman's coefficient rank correlation in order to detect differences and similarities in the living and working conditions, health status and quality of life of urban and rural population. Quality of life can be measured by with the use of a number of techniques. So the quality of life can be measured simultaneously from both the perspective of objective and subjective evaluation factors. The combination of multiple research approaches on same subject of research overcomes some of the weaknesses and problems of individual research methods and thus improve the results of research (Milivojević et al, 2015).

Table 1: Methodological pluralism which is applied when measuring quality of life

\begin{tabular}{|c|c|c|}
\hline System Level & Focus of measurement & Strategy measurements \\
\hline Micro System & $\begin{array}{l}\text { Subjective nature of quality } \\
\text { life ("personal assessment") }\end{array}$ & $\begin{array}{l}\text { Satisfaction research } \\
\text { Measuring happiness }\end{array}$ \\
\hline Central system & $\begin{array}{l}\text { Subjective nature of quality } \\
\text { life ("functional assessment") }\end{array}$ & $\begin{array}{l}\text { Coding scale (level of functioning) } \\
\text { Observation of participants } \\
\text { Questionnaires (external events } \\
\text { and circumstances) } \\
\text { Engaging in everyday activities } \\
\text { Self-determination and personal } \\
\text { control } \\
\text { The role of status (education, work, } \\
\text { everyday life) }\end{array}$ \\
\hline Macro system & $\begin{array}{l}\text { External conditions ("social } \\
\text { indicators") }\end{array}$ & $\begin{array}{c}\text { Life standard } \\
\text { employment rate } \\
\text { literacy Rate } \\
\text { mortality rate } \\
\text { Expected life }\end{array}$ \\
\hline
\end{tabular}

Source: Schalock (2004).

The aim of the quality of life conception cannot be seen only in the way of identifying particular problems, but also to point out the possibilities of their solution and outline the direction the society has to follow in a sense to ensure the satisfactory degree of quality of life for all. Hopefully, the presented paper at least partially contributed to explanation and support of the status of geography and geographers in this endeavor (Andraško, 2009). 


\section{Analysis and discussion}

Planning rural and urban development, and even more measurement and assessment of its results, it is necessary mean definition and selection of appropriate indicators. In the literature most often cite subjective and objective indicators of quality of life._An objective approach is based on the study of the representation of various external indicators such as: material situation, state of the environment, political freedom, the level of democracy in society..., while the subjective approach mainly deals with the subjective experiences and the experiences of individuals. The issue of objective and subjective approach to quality of life is engaged in numerous authors. On this occasion, among them apostrophized: Thompson et al, 1962; Lewis, 1968; Bunge, 1973; Smith, 1973; Knox and MacLaran, 1978; Frazier, 1982; Helburn, 1982; Sufian, 1993; Oliver et al, 1995; Johnston, 1997; Diener and Suh, 1997; Diner et al, 1999; Hargety et al, 2001; Massam, 2002; Scollon et al, 2003; KaÚeman and Krueger, 2006; Ira and Andraško, 2007; Heady, 2008; Brereton et al, 2008; Slavuj, 2012; Rajović and Bulatović, 2016; Rajović and Bulatović, 2016.

Table 2: Three dimensions of quality of life

\begin{tabular}{|c|c|c|}
\hline Dimensions & & Main domain \\
\hline \multirow{6}{*}{$\begin{array}{c}\text { Have } \\
(\mathrm{H})\end{array}$} & 1 & Economic resources \\
\hline & 2 & Housing conditions \\
\hline & 3 & Employment \\
\hline & 4 & Working conditions \\
\hline & 5 & Health \\
\hline & 6 & Education \\
\hline \multirow{5}{*}{$\begin{array}{c}\text { Love } \\
\text { (L) }\end{array}$} & 1 & Contacts in the local community \\
\hline & 2 & Contacts in the family \\
\hline & 3 & Friendships \\
\hline & 4 & Contacts in associations and organizations \\
\hline & 5 & Relationships at workplace \\
\hline \multirow{5}{*}{$\begin{array}{l}\mathrm{Be} \\
\text { (B) }\end{array}$} & 1 & Participation in decision-making in relation for own life \\
\hline & 2 & Political activities \\
\hline & 3 & Opportunities for rest and recreation in free time \\
\hline & 4 & Opportunities for creative work \\
\hline & 5 & Opportunities for enjoy nature \\
\hline
\end{tabular}

Source: Arsovski and Stojković(2014).

Quality of life can be considered according to Arsovski and Stojković (2014) as a synthesis of three approaches: resources and standards of living of people (Have-H), subjective experience, or perceived quality of life (Love - L), possibility of individual promotions and satisfaction ( $\mathrm{Be}-\mathrm{B}$ ), as shown in Table 1.

Table 3: Differences dimension QoL

\begin{tabular}{|c|c|c|}
\hline Objective living conditions & \multicolumn{2}{|c|}{ Subjective feeling Quality of Life } \\
\hline & Good & Poor \\
\hline Good & Good feeling & Dissonance \\
\hline Poor & Adapting & Deprivation \\
\hline
\end{tabular}

Source: Arsovski and Stojković (2014) according to Rapley, 2003.

According to Milivojevic et al (2006), the index of quality of life (objective) is determined based on previously obtained values of each of the sets of indicators, mainly using the method of logical reasoning. So, if you take the total number of negative points from 1 to 20 defines the scale quality of each of the sets of indicators. Then, based on the evaluation of all four sets of indicators (economy, society, environment and science and technology), defines the index of quality of life. Therefore, according Milivojević et al (2006) Quality of life is defined as: excellent, above average, average, below average and bad. Satisfaction with quality of life (subjective) involves personal 
evaluation of what we have, love and create (jobs, education, family, children, friends, career ...), but also other factors such as health, material wealth, organization and quality of the state... The index of satisfaction with quality of life gets research on a representative sample of the population of an area (city, region, country) where the index evaluates each individual and calculating the satisfaction index from the set value of the indicator (scale of 1 to 5 ).

Table 4: Alternative approaches to knowledge about quality of life

\begin{tabular}{|c|c|c|c|c|}
\hline \multirow[b]{2}{*}{ Distinctions } & \multicolumn{4}{|c|}{ Approaches } \\
\hline & $\begin{array}{c}\text { Livability } \\
\text { comparisons }\end{array}$ & Wage differentials & $\begin{array}{l}\text { Personal well- } \\
\text { being }\end{array}$ & Community trends \\
\hline $\begin{array}{l}\text { Origins of } \\
\text { professional } \\
\text { approach } \\
\end{array}$ & $\begin{array}{l}\text { Journalism, } \\
\text { geography, or } \\
\text { other } \\
\end{array}$ & Economics & $\begin{array}{l}\text { Psihology, } \\
\text { sociology }\end{array}$ & $\begin{array}{l}\text { Recommended } \\
\text { approach for } \\
\text { pllaners } \\
\end{array}$ \\
\hline $\begin{array}{l}\text { Measurement } \\
\text { focus }\end{array}$ & $\begin{array}{l}\text { Shared, objective } \\
\text { characteristics } \\
\text { of communities } \\
\text { using secondary } \\
\text { data }\end{array}$ & $\begin{array}{c}\text { Disamenity } \\
\text { compensation } \\
\text { using secondary } \\
\text { data }\end{array}$ & $\begin{array}{c}\text { Determinants of } \\
\text { life } \\
\text { satisfaction based } \\
\text { on personal } \\
\text { interviews }\end{array}$ & $\begin{array}{c}\text { Local trends in } \\
\text { components } \\
\text { of quality of life } \\
\text { using } \\
\text { secondary data } \\
\text { and personal } \\
\text { interviews }\end{array}$ \\
\hline Statistical means & $\begin{array}{c}\text { Additive } \\
\text { combinations of } \\
\text { objective } \\
\text { indicators using } \\
\text { weights supplied } \\
\text { by researcher } \\
\text { judgment }\end{array}$ & $\begin{array}{c}\text { Regression models } \\
\text { estimating } \\
\text { weighted } \\
\text { contribution of } \\
\text { objective } \\
\text { amenities to wage } \\
\text { differentials } \\
\text { between places }\end{array}$ & $\begin{array}{c}\text { Regression models } \\
\text { estimating } \\
\text { weighted } \\
\text { contribution to } \\
\text { self- } \\
\text { evaluations of } \\
\text { different life } \\
\text { domains to overall } \\
\text { life } \\
\text { satisfaction }\end{array}$ & $\begin{array}{l}\text { Objective indicator } \\
\text { profile of } \\
\text { changing } \\
\text { community } \\
\text { character and } \\
\text { subjective } \\
\text { citizen assessment } \\
\text { of each } \\
\text { separate factor }\end{array}$ \\
\hline $\begin{array}{c}\text { In past has } \\
\text { directed attention } \\
\text { to }\end{array}$ & $\begin{array}{l}\text { Which places are } \\
\text { "better" or "worse" }\end{array}$ & $\begin{array}{c}\text { Which places must } \\
\text { pay } \\
\text { higher wages }\end{array}$ & $\begin{array}{c}\text { Personal } \\
\text { characteristics and } \\
\text { private life }\end{array}$ & $\begin{array}{l}\text { Which factors are } \\
\text { growing } \\
\text { better or worse - } \\
\text { emphasis } \\
\text { on the future and } \\
\text { citizen } \\
\text { priorities }\end{array}$ \\
\hline $\begin{array}{l}\text { Political/economic } \\
\text { implications } \\
\text { of past work }\end{array}$ & $\begin{array}{l}\text { Aids competition } \\
\text { for relocating } \\
\text { firms and workers }\end{array}$ & $\begin{array}{c}\text { Indicates } \\
\text { lower/higher costs } \\
\text { of doing business }\end{array}$ & $\begin{array}{l}\text { Local government } \\
\text { cannot } \\
\text { help much }\end{array}$ & $\begin{array}{c}\text { Highlights local } \\
\text { problems } \\
\text { and goals related } \\
\text { to } \\
\text { development } \\
\text { process }\end{array}$ \\
\hline
\end{tabular}

Source: Massam (2002) according to Myers (1988).

Table 4 indicates that summarize the major differences among major alternate approaches to measuring QOL. Massam (2002) citing research Myers (1988) points out that He notes five major distinctions: "First, what have been the scientific or professional origins of each approach? Second, how does each approach focus its measurement process regarding quality of life? Third, what is the statistical basis for measuring quality of life? Fourth, what aspects of quality of life have the conclusions of such studies emphasized in the past? And finally, what political or economic implications have been drawn from such studies in the past?”.

Table 5: Advantages and disadvantages of alternative approaches measuring QOL 


\begin{tabular}{|c|c|c|}
\hline Livability comparisons & $\begin{array}{l}\text { Livability comparisons } \\
\text { yield a practical set of } \\
\text { qualitative } \\
\text { measurements that } \\
\text { many users are eager to } \\
\text { accept as useful } \\
\text { representations of other } \\
\text { people's cities }\end{array}$ & $\begin{array}{c}\text { A lack of theory to guide measurements } \\
\text { seems to be at the root of the criticism. } \\
\text { Researchers impose their own } \\
\text { assumptions and input their own } \\
\text { priorities when selecting and weighting } \\
\text { indicators. } \\
\text { The weights attached to different } \\
\text { components are arbitrary and thus yield } \\
\text { erroneous ratings of overall quality of } \\
\text { life. } \\
\text { Place comparisons are not designed to } \\
\text { measure quality of life as residents see } \\
\text { it. } \\
\text { By focusing on making comparisons } \\
\text { between areas, features that define } \\
\text { quality of life in particular areas may be } \\
\text { ignored. } \\
\text { The methodology biases the quality of } \\
\text { life scores to favour larger areas. }\end{array}$ \\
\hline Wage differentials & $\begin{array}{l}\text { The citizen preferences } \\
\text { can be measured from } \\
\text { market behavior } \\
\text { The evidence to support } \\
\text { the theory that quality of } \\
\text { life improves business } \\
\text { climate }\end{array}$ & $\begin{array}{l}\text { Since researchers have tested only a } \\
\text { very limited range of variables to } \\
\text { determine how they represent quality of } \\
\text { life, the research is not yet broadly } \\
\text { applicable. } \\
\text { The omission of housing and cost of } \\
\text { living from the definition creates a gap } \\
\text { between the technical and popular } \\
\text { definitions of quality of life. } \\
\text { When combined with the extreme } \\
\text { complexity of the methodology wage } \\
\text { differential research loses its salience \& } \\
\text { potential for local use. }\end{array}$ \\
\hline Personal well-being & $\begin{array}{l}\text { This approach can be } \\
\text { valuable for some } \\
\text { purposes. Local } \\
\text { decision-makers might } \\
\text { benefit from knowing } \\
\text { the importance, for } \\
\text { example, recreation } \\
\text { plays in residents' } \\
\text { personal quality of life. }\end{array}$ & $\begin{array}{l}\text { Studies focus on personal well-being } \\
\text { often fails to meet community } \\
\text { purposes, because defining quality of } \\
\text { life in personal terms has important } \\
\text { limitations. } \\
\text { The measurements provide a less useful } \\
\text { guide for community level decisions. }\end{array}$ \\
\hline
\end{tabular}




\begin{tabular}{|c|c|c|}
\hline Community trends & $\begin{array}{c}\text { This approach } \\
\text { emphasizes trend over } \\
\text { time while } \\
\text { conceptualizing quality } \\
\text { of life as a part of the } \\
\text { ongoing development } \\
\text { process. } \\
\text { It encourages interest } \\
\text { groups to participate in } \\
\text { negotiating what factors } \\
\text { should be measured as } \\
\text { part of the quality of life. }\end{array}$ & $\begin{array}{c}\text { It should be avoided to formulate } \\
\text { community well-being on the basis of } \\
\text { personal well-being. Community well- } \\
\text { being stresses community factors that } \\
\text { are beyond individual control while } \\
\text { personal well-being stresses private, } \\
\text { personal matters that are largely } \\
\text { beyond governmental control. }\end{array}$ \\
\end{tabular}

Source: Baycan Levent and Nijkamp (2006)

Although each approach provides some useful information about QoL, they all have some weaknesses. Table 5 shows advantages and disadvantages of each alternative approaches.

Table 6: Two main approaches in defining the values of objective indicators

\begin{tabular}{|c|c|}
\hline No statistical methods & Statistical methods \\
\hline Assessment researchers & Regression analysis \\
Expert evidence & Factor analysis \\
Literature & \\
Survey research and focus groups & \\
\hline
\end{tabular}

Source: Slavuj (2014), according to Eyles (1994); Wong (2006) Malkina-Pykh and Pykh (2008).

According to Slavuj (2014) (citing research Eyles, 1994; Wong, 2006; Malkina-Pykh and Pykh, 2008) possible to separate the two main approaches to defining the values of objective indicators: points out that it is possible extract two main approaches that are used in research are applied to define the values of objective indicators: non-statistical methods and statistical methods. In non-statistical methods may include: self-assessment authors of the study, the opinion of experts, and the literature devoted to the same or similar issues and research of public opinion through polls or focus groups. The most are widely statistical methods to calculate the values of objective indicators of the analysis of regression and factor analysis. When it comes to the value of subjective indicators, and gathering information about the overall quality of life, according to Slavuj (2014), citing Dzurova and Dragomirecka (2000), Trauer and Mackinon (2001), Alcazar and Andrade (2008) it is possible to multiply the results of satisfaction with the results of importance to every domain of life, and then opted for summing the results of in index.

\section{Expressed formula: Subjective quality of life $=\Sigma$ (satisfaction domain $x$ importance of domain).}

For example, if the research uses Likert scale with five points, and expressed satisfaction with some of the domains of life is 3 degrees, and the importance she attaches to 4 , then the score for that domain was 12. The process must be repeated for each domain and then count their results in order to obtain a complex subjective index. The value of the importance of the relatively are common procedure used in the formation of a subjective index of quality of life and to individual researchers count as correct.

Since 2011, the Eurostat indicators used QLI (Quality of Life Indicators). It measures eight dimensions of well-being. At Euro Fund (Euro found - European Foundation for the Improvement of Living and Working Conditions) has formed a database of statistics quality of life (Euro LIFE). The base consists addicted collected in the European quality of life research (European quality of life survey- EQLS), which is based on data from a total of 160 indicators of quality of life, classified into 12 groups. Based on the following analysis of literature (Kuz, 1978; Omuta, 1988; Tuain Seik, 2000; Santos and Martins, 2007; Priego et al, 2008; Feneri et al, 2013; Rezvani et al, 2013; Rosu et al, 2015) and present knowledge, in this paper "Comparative analysis of living conditions in the 
settlements Municipality of Berane and settlements Municipality Andrijevica, "we used procedure have implemented Kajari and Šandor (2011), adapted for the purposes of this research.

Table 7: Age structure of interviewees

\begin{tabular}{|c|c|c|}
\hline Year & Frequency & $\%$ \\
\hline $18-30$ & 31 & 34.06 \\
\hline $31-40$ & 25 & 27.48 \\
\hline $41-50$ & 18 & 19.78 \\
\hline $51-60$ & 11 & 12.09 \\
\hline 60 and more & 6 & 6.59 \\
\hline Total & 91 & 100 \\
\hline
\end{tabular}

From a total of 91 respondents in the study included 48 men or $52.74 \%$, respectively 43 women or $47.26 \%$. Table 7 shows the distribution of respondents by age. The majority of respondents $34.06 \%$ were in the age group of 18 to 30, while the total number of respondents in the age group of 31 to 40 years accounted for $27.48 \%$, in the group from 41 to 50 years $19.78 \%$, from 51 to 60 years $12.9 \%$ of respondents in the age group 60 and over, there were only $6.59 \%$ of respondents.

Table 8: Education of respondents

\begin{tabular}{|c|c|c|}
\hline Education of respondents & \multicolumn{2}{|c|}{ Structure in \% } \\
\cline { 2 - 3 } & Rural ssettlement & Urban settlement \\
\hline Primary school & 61.54 & 14.29 \\
\hline Secondary school & 35.16 & 71.43 \\
\hline College & 3.30 & 9.89 \\
\hline Faculty & - & 4.39 \\
\hline Total & 100.00 & 100.00 \\
\hline
\end{tabular}

Analysis received answers show that interviewed people in rural settlements in the municipality of Berane and Municipality Andrijevica lags for the urban population in terms of education. Specifically, the total number of respondents (91) was involved in the study of the total number of respondents in rural settlements 51 of them, of which the primary school was not for them $61.54 \%$, with secondary education $35.16 \%$, with college education $30.3 \%$. The educational structure of the total number of respondents in urban settlements Berane and Andrijevica (40) in the survey were involved with primary school 14.29\%, with college education (includes and students) $9.89 \%$ and the faculty $4: 39 \%$ of respondents. According to most of the findings from the literature educational level was positively associated with pleasure and happiness (Ruff et al, 1999; Kling and Wing, 1999; Nezlek, 2000; Markus et al, 2004; Ryan and Huta, 2009) which is logical given that a higher level of education an individual provides a greater range of opportunities and resources available.

Table 9: Occupation of respondents

\begin{tabular}{|c|c|c|}
\hline \multirow{2}{*}{ Occupation } & \multicolumn{2}{|c|}{ Structure in \% } \\
\cline { 2 - 3 } & Rural ssettlement & Urban settlement \\
\hline Pupil / Student & 7.84 & $\mathbf{1 7 . 5}$ \\
\hline Agriculturist & 17.65 & $\mathbf{2 2 . 0}$ \\
\hline A worker in a state institution & 9.80 & 10.0 \\
\hline Entrepreneur & - & 12.5 \\
\hline Housewife & 15.69 & 10.0 \\
\hline Pensioner & 25.49 & 22.5 \\
\hline An unemployed person & 23.53 & 100.00 \\
\hline Total & 100.00 & \\
\hline
\end{tabular}


Many theorists believe that occupation can have large effects on the extent and factors of employee satisfaction. Job satisfaction is a strong indicator of positive attitudes and determined individual and organizational values (Diaz - Serrano and Vieira, 2005). Table 8 shows the interest of survey respondents. Significant differences between rural and urban populations can be observed almost in all professions. Examples of Table 3 confirm this. Namely, in professions pupil /student difference is in the range $7.84 \%-17.5 \%$, the farmer $17.65 \%-5.0 \%$, a worker at a state institution $9.80 \%-22.5 \%$, housewives $15.69 \%-12.5 \%$, a pensioner $25.49 \%-10.0 \%$, the unemployed face $23.53 \%-22.5 \%$.We note that interest entrepreneur is not present in the surveyed rural population, while the share of entrepreneurs in the urban settlements of Berane and Andrijevica amounts $10.0 \%$. Barriers to entrepreneurship are reflected in the lack of initial capital, the uncertainty of the economic environment, credit disability, lack of knowledge and skills for entrepreneurship, lack of confidence and support. Location municipal administration in urban settlements, and schools and health care necessarily imposes a greater participation of workers in urban areas. The consequence is the fact that in rural areas, local governments as well as the educational and health institutions shall perform only small jobs and tasks. Similar is the situation of occupations pupil /student. The majority of young people forced to during training or studying living or traveling in urban settlements. Respondents most Valuable problems related to unemployment. The number of unemployed persons in the surveyed respondents is almost even. The quality of labor supply due to lower levels of education and low competence working-age population is at a critical level. A number of respondents were forced to seek sources of social security in the system of social protection. According to Rajović and Bulatovic (2015) the most important sources of income from agriculture for household income generated from livestock production (livestock, meat, milk, eggs). Participation of farmers in total employment structure is the result of an unstable market for agricultural products, inadequate and insufficiently specialized production structure, low productivity, lack of mechanization ... all of which cause the revenues earned by selling agricultural products have not been identified as the most relevant for survival and perspective of households. In these new circumstances, European and world experience shows the tendency to develop a permanent system of education, and that the problem occupations increasingly comes to the fore as a strong indicator of good business and prosperity (Ross and Reskin, 1990; Spector, 1995; Clark, 1996; Gaziouglu and Tansel, 2002; Fabra and Camison, 2009). The social status of a housewife is conditioned by a marked income inequality. They are doubly marginalized, as members of agricultural households and as women within the economic and family organization of their households. Their social status cannot be improved without improving the position of agricultural households, which generally do not achieve even a modest income, or better conditions for the employment of those women that their economic status want to establish outside the household. According to the annual report "Age Watch Index" on the status of the aging population, published by the organization "Help Age International", followed by the fact that of the 91 countries ranked, Montenegro was given not at all pleasant place 83 (www.vijesti.me). Countries are ranked by of security wages, health care, per capita GDP, the environment and the school system, as well as the by the social environment. The average pension in Montenegro amounts 276.20, while more than a thousand pensioners receive a minimum pension of 100 Euros. The question is how and what this group of pensioners can reconcile the basic necessities of life, not to mention the need of treatment, and almost daily visits to the hospital and health centers.

Table 10: Residential conditions of respondents

\begin{tabular}{|c|c|c|}
\hline $\begin{array}{c}\text { The quality and ownership of living } \\
\text { space }\end{array}$ & \multicolumn{2}{|c|}{ Structure in\% } \\
\hline & Rural ssettlement & Urban settlement \\
\hline Luxury house / apartment & 17.65 & - \\
\hline Own & 17.65 & - \\
\hline Leased & - & 32.50 \\
\hline Own & 23.53 & 32.50 \\
\hline Leased & 23.53 & - \\
\hline
\end{tabular}




\begin{tabular}{|c|c|c|}
\hline Average house / apartment & 49.02 & 62.50 \\
\hline Own & 49.02 & 57.50 \\
\hline Leased & - & 5.0 \\
\hline No comfortable house / apartment & 9.80 & - \\
\hline Own & 9.80 & - \\
\hline Leased & - & 100.00 \\
\hline Total & 100.00 & \\
\hline
\end{tabular}

The research results indicate some differences in the structure of living space of respondents by place of residence. Thus, respondent's villages $49.02 \%$ of them have an average house /apartment, while $62.50 \%$ of respondents in urban areas have the same quality of living space. Comfortable house in the village has a $23.53 \%$ of respondents, while in urban settlements is $32.50 \%$ of them. The luxurious house in rural settlements has $17.65 \%$ of respondents, while this phenomenon cannot perceive among respondents in urban settlements Berane and Andrijevica. Precisely this residential condition indicates the social differentiation of respondents, that luxury houses have mostly interviewees in rural settlements - temporary workers abroad. No comfortable houses/apartments among are respondents in urban settlements are not recorded, while in rural areas the share of these objects is $9.80 \%$. As for ownership of housing both among rural and among urban respondents housing was almost in their own property. "Mild difference which is owned residential buildings appear in favor of the rural population is the result of the fact that the rural population is less - and more work related to the village in which conducts agricultural production, and is less mobile than the city. In his case, it is quite rational behavior to settle permanently in the village, in their own home and work the land in the environment. When it comes to urban populations, their professional mobility is more pronounced, because as an administrative worker, doctor, teacher ... anywhere you can get a job, and had no interest in acquiring ownership of the housing reduce their mobility, mobility in the labor market "(Kajari and Šandor,2011).

According to Svirčić Gotovac (2006) equipped households depend on the technical equipment. Households can be equipped with basic or primary technical conditions and secondary conditions that are above the level of basic conditions. The natural conditions in the household are: electrification (electricity), water (running water), heating, sewage, bathroom, and other supplementary installations. Today, the prim Secondary conditions household equipment according to Svirčić Gotovac (2006) makes the existence of technical facilities and devices for daily functioning of life, such as household appliances, phone, and all those less basic but modern and necessary installations, such as connection to the Internet.ary level reached modernizing filled in most developed countries and developing countries. In this second type of equipment levels to satisfy all or just some of the needs becomes dependent on many indicators, and thus are harder to objectively determine. For example, depending on educational attainment population, total income in the household or some personal and subjective preferences and aspirations, this level of equipment can vary widely.

Our research evidence based on similar studies to Bokić and Čikić ( $\left.{ }^{* * *}\right)$ indicate that the rural population is characterized by the differentiation in terms of quality and ownership of living space by source of income in the household. The results confirm the assumption that the sources of household income determined by the tendency towards certain types of investments and their real possibilities. If the Size of living space viewed as an expression of investment in non-production factors, then it is understandable why pure agricultural households have the lowest residential area. On the other hand, mixed holdings have increased the quality of living space due to the dual sources of the family budget, a specific attitude towards investment... Drug Indicator dimensions housing include equipped household. Research shows that significant differences in the influence of certain socio-cultural factors on the quality of equipped and of living space no. Significant differences in the equipment of households in the village and the city were present only in the possession of modern technical equipment (for example air conditioning) and communication means (internet). Also, there are "read" the impact of income sources as a factor that contributes to the internal differentiation of rural households with regard to possession of modern means of communication and sources of information, so that the non-agricultural households that the one are in the majority of possess. 
Quality of life related to health can be defined as "an optimal level of mental, physical, occupational and social functioning, including relationships with the environment, as well as the feeling of health, physical condition, life satisfaction and well-being. Modern medicine according to Knight et al (2001), Alonso et al (2004), Efklides et al (2006) and Trgovčević et al (2014) indicate that in addition to the extension of life expectancy, as a goal increasingly focuses on improving quality of life. At the global quality of life certainly affect aspects of the environment (air and water quality), geographical conditions (land configuration, climate), economic aspects (standards, employment), social interaction and positive life experience. Orientation towards the patient's "good health" (the opposite of the orientation disease), leading to the development of the new term quality of life related to health and quality of life related to health (Health related quality of life HRQL or HRQoL).

Table 11: The health status of respondents

\begin{tabular}{|c|c|c|}
\hline \multirow{2}{*}{ Mark } & \multicolumn{2}{|c|}{ Share in\% } \\
\cline { 2 - 3 } & Rural ssettlement & Urban settlement \\
\hline Not knows - o & 3.25 & 2.37 \\
\hline Very bad - 1 & 1.74 & 9.35 \\
\hline Bad - 2 & 3.18 & 6.04 \\
\hline Sensitive - 3 & 11.07 & 21.67 \\
\hline Good - 4 & 57.89 & 40.54 \\
\hline Excellent - 5 & 22.87 & 20.03 \\
\hline Total & 100.00 & 100.00 \\
\hline
\end{tabular}

Respondents in rural settlements have their health assessed predominantly as good - 4 (57.89\%) and doing great - 5 (22.87\%), while respondents in urban settlements their health status assessed as good $-440.54 \%$ and grade excellent - 5 of them $20.03 \%$. We note the disproportion in the answers rural and urban respondents who rated their health very badly (1.74\%-9.35\%), bad (3.18\%-6.04\%), sensitive (11.07\% - 21.67\%), while the number of those who declared themselves respondents not knows (2.37\% - 3.25\%). According to Mirković and Simić (2011) self-perceived health is generally accepted by many researchers as a reliable indicator of health status. Specifically, it was found that self-reported health status of a powerful predictor of diseases, functional capacity, and especially an independent predictor of mortality (Okosun et al, 2001; Bath, 2003; Bond et al, 2006; Ford et al, 2008; Norekval et al, 2010). Furthermore, according to Mirković and Simić (2011) meta-analysis Idler and Benyamini (1997) shows that in 23 of 27 studies self-reported health status accurately predicts survival or life expectancy, or significant predictor of decreased functional activity (Idler et al, 1999; Mansson and Rastam, 2001; Kaplan and BaronLeplen, 2003) and use of health services and hospitalization (Menec and Chipperfield, 2001; DeSalvo et al, 2005). Understanding the connection only of estimated the health status of the determinants of health can help health care professionals to adapt to health promotion and preventive activities in accordance with the needs of the population (Philips et al, 2005).

Table 12: Satisfaction of respondents through life

\begin{tabular}{|c|c|c|}
\hline \multirow{2}{*}{ Mark } & \multicolumn{2}{|c|}{ Share in\% } \\
\cline { 2 - 3 } & Rural ssettlement & Urban settlement \\
\hline I am pleased & 29.47 & 31.26 \\
\hline Partially I am satisfied & 59.03 & 55.84 \\
\hline Dissatisfied & 11.50 & 14.88 \\
\hline Total & 100.00 & 100.00 \\
\hline
\end{tabular}

The satisfaction or dissatisfaction as an element of quality of life conditions of the rural and urban population, we compared the level of their satisfaction: family life, current job, living standards, access to social and public services, participation in local community life, technical infrastructure, availability of institutions and organizations, traffic and communal services. Possible ratings ranged from 1 to 5 , with the following content: disagree I satisfied - 1 , not satisfied 
- 2, moderately am satisfied - 3, I am satisfied - 4, I'm very pleased with 5 . The social life of the population in rural areas is significantly different from the life of the urban population. While the city offers numerous cultural, entertainment and sports facilities in different institutions, their village residents provides space community house as a meeting place and leisure time. Of given categories respondents were most satisfied with family life that on a scale of 1 to 5 assessed with 4.41; on the other hand the survey showed that respondents were also the lowest level of satisfaction expressed by the present work, which are rated with an average score of 0.43 . Also, there is a low level of satisfaction towards the standard of living (average score 0.49). Observed by gender Men are more satisfied with family life that is rated with 4.2, while women family life assessed with 3.9. If we look to the type of settlement we can note that the respondents from urban and rural areas gave almost identical scores, the only difference we see in the field of satisfaction with education, where respondents from the rural part of the evaluation gave 1.74, while respondents from the urban part of the education rated with 3.62. Respondents in rural settlements (62.4\%) indicates the dominant issue, it is limited access to social and public services, and capital market .Thus, for example, access to health care and financial services (ambulance, pharmacy, post office) is not adequate to the needs of rural settlements. Financial services (post office) almost do not exist. There are some rural services such as separate departmental primary school, shops and local offices, playground... The greatest pleasure for of respondents from rural areas (75.8\%) was expressed in connection with the available health services and cultural life in the village as well as the problem of lack of technical assistance in agricultural production. Among the respondents, the more of them is not enough for the work of local administration bodies (respondents in rural settlements - 52.3\%; respondents in urban settlements - 48.4\%). If this is added to those who are satisfied with the work of these bodies to a lesser extent (respondents in rural settlements -38.9\%; respondents in urban settlements - 32.7\%) then even $8.8 \%$ of respondents in rural settlements, or $18.8 \%$ of respondents in urban settlements has objections to the work of the local administration. More complete picture of the participation of such dimension of quality of life obtained was introduced into added if the respondents personally willing to engage in activities that would be aimed at solving local problems. The majority of respondents in rural settlements (58.4\%) as in urban settlements (51.7\%) stated that it is willing to engage in activities that would contribute to improving the quality of life. When it comes to technical infrastructure, surveyed respondents are generally dissatisfied because the average score for all categories except telecommunications infrastructure (average score 1.41), on a scale of 1-5. Research has shown that citizens in addition to telecommunications infrastructure, the most satisfied electrical energy infrastructures which are on a scale of $1-5$ ratings with an average score of 2.86 . Followed by water infrastructure (1.38), parking (1.47), while respondents in urban settlements at least satisfied with the cleanliness of the city with an average score (2.05). If we look to the type of settlement we can note that the respondents from urban and rural areas and these questions have given nearly identical scores, the only difference we see in the assessment of transport infrastructure-water supply and where respondents from urban areas showed slightly higher levels of satisfaction. Respondents from rural areas are most satisfied with the telecommunications (score 2.12), while the least satisfied with the organization of public transport (0.43).

Table 13: Rank the reasons for the concern of respondents

\begin{tabular}{|c|c|c|c|}
\hline \multirow{2}{*}{ A cause for concern } & \multicolumn{2}{|c|}{ Rank reasons } & \multirow{2}{*}{ All respondents } \\
\cline { 2 - 3 } & Rural ssettlement & Urban settlement & 1 \\
\hline Lack of money & 1 & 1 & 2 \\
\hline Unemployment & 2 & 2 & 6 \\
\hline Residential conditions & 6 & 6 & 4 \\
\hline Education of children & 4 & 4 & 5 \\
\hline Health Problems & 5 & 3 & 3 \\
\hline Founding family & 3 & 5 & \\
\hline
\end{tabular}

Lack of money and employment for all respondents, regardless of their place of residence is the most important reason for concern. It is followed by the rural population are starting a family, children's education, health problems and housing conditions. In the urban population in third 
place are the health problems, and children's education, starting a family and housing conditions. Considering to take and the rural and urban populations housing problems can be considered resolved, the concern is with both groups in last place. The low employment rate is one of the major causes of depopulation. All this points to the need for taking are urgent measures to create new and safeguard existing jobs. Poverty caused by demographic and economic decline, with growing social consequences and the low living standards of the population is particularly prevalent in rural areas, where the highest rate of unemployment. The three dominant issues in the municipality of Berane and Andrijevica are poor and underdeveloped infrastructure, weak competitiveness and underdeveloped economy and limited access to social and public services and capital markets. The current economic development in the first place was tied for the use of resources for agriculture through involvement of less skilled workforce. Agricultural production is extensive and not market-oriented, based on outdated machinery and technology. Low productivity is caused by a small live stock and bad racial composition of cattle appears as problem. Average agriculturally active household has up to $2-3$ livestock unfavorable racial composition and small production facilities. Crop and animal production can be summarized mainly for their own use, while a small part of the intended market. The fruit production is observed a lack of adequate capacity for processing. Lack of organized and secure whence impact on reducing livestock numbers and the volume of agricultural production. As a reason for the poor entrepreneurship, respondents mention the complicated administration and lack of funds for investment. Insufficient resources withdrawal and are weak marketing and the advent of the market for entrepreneurs from this area very difficult.

\section{Conclusion}

Our research evidence based on similar studies Sabbah et al (2003), Oguzturk (2008), Slavuj (2012), Cartra et al (2012), DosSantos et al (2014), points to the following conclusions:

1. First, the fundamental geographic research problems quality of life in the 1970s of the last century is primarily used objective measures. But very quickly there are works that apply a subjective measure. Those papers were encouraged by strengthening the knowledge about the importance of perceptions and experiences of the individual, and a sense that they have towards them. Today, the geographic studies combine both objective and subjective indicators of quality of life,

2. The tendency of people to provide estimates of satisfaction that are mainly focused on the positive side of the scale is well known effect in studies of quality of life. Many studies (Marans and Rogers, 1975; Campbell et al, 1976; Wellman and Wortley, 1990; Lu, 1999; Parkes et al, 2002), Lovejoy et al (2010) according to Slavuj (2012) revealed a tendency towards a positive evaluation neighborhood. The literature as a potential explanation for this effect most commonly cited: the tendency of individuals to adapt and adjust to the residence from which they do not have opportunities to move out, especially in the case if they were readily available resources outside their immediate place of residence; the possibility that individuals settled in neighborhoods which prefer; the possibility that such widespread satisfaction with the giving of testimony reflects a lack of concern or interest to the neighborhood,

3. Having "roof over your head," according to the Slavuj (2012) means to possess the most intimate space for relaxation, privacy, security, and social interaction. Housing affects not only the satisfaction of physical needs, but also plays an important role in ensuring a person's private space in which individuals can fulfill their personal aspirations without a significant influence of external factors. Thus, the Slavuj (2013) concludes by referring to research Grayson and Young (1994) to residential therefore can pose both physical and emotional basis for a good quality of life. On the other sides in the absence of house/apartment people cannot meet their basic needs. Therefore, housing is considered one of the most important factors affecting the quality of life. The research results confirm the assumption that in rural and urban areas of the municipality Berane and Municipality Andrijevica sources of income in the household determine propensity towards certain types of investments and their real possibilities, i.e. that the housing considered geo-space is not an obstacle to the functioning of the surveyed individuals or families,

4. Key measures to improve life in the municipalities of Berane and Andrijevica, according to $74.3 \%$ of respondents in rural settlements and $81.2 \%$ of respondents in urban settlements is creating new jobs and increasing employment. Stands out with the importance of investing in social and community infrastructure (respondents in rural settlements - 64.8\%; respondents in urban settlements - 52.4\%) citing the following measures: drinking water for all, arranging places 
and playgrounds, construction of sewers, renovation of local roads, landscaping schools, more cultural events, equipment shops settlement, restoration ambulances...,

5. This remark is significant precisely because it points to inadequate and insufficient equipment of rural settlements even elements of primary infrastructure, which are not met even the basic conditions for the overall quality of life. Maintaining such a situation does not provide the opportunity for quality development planning. Using research Bogadi Klempić et al (2011) in this text points to part of them $39.6 \%$ of respondents considered important measure of progress to support young people. It is necessary to support their ideas, but also to improve the educational structure of the villages to encourage them to higher education, awarded scholarships to the best, allow them to creatively spend their time, organize training courses and workshops to be studied previously acquired knowledge and exchanging ideas. As an important factor in improving the lives of the population recognized the need to stimulate the development of local entrepreneurship (41.9\%),

6. Remaining proposals appear in rarely so it will only be listed here: investment in tourism development (especially rural, excursions, sports and recreation) (see Rajović and Bulatović, 2015), to support the development of agricultural production, improving cooperation with residents, providing assistance needs (the elderly and weaker groups), and to encourage self-employment. Almost the majority of respondents in urban settlements (62.4\%) and rural (67.5\%) cited various measures to improve the quality of life in the village municipality of Berane and municipalities Andrijevica. Answers include proposals: equality for all residents, taking measures against emigration, employment, encouraging the development of rural areas because they are the future of a healthy life, running activities for young people and the elderly population, the introduction of bus transport,

7. Some answers may respondents the interpreted distrust of local government, so it would seem necessary in the future development plans of municipalities to a greater extent involve locals in order to build trust between residents and local government, which is an essential prerequisite for successful implementation,

8. Quality of life has been intensified in recent decades. Between researchers, spatial planners and representatives of the authorities towards the Slavuj (2012), citing research Tuan Sheikh (2000), Li and Weng (2007) stresses that there is a consensus in which studies on quality of life is extremely necessary because the research results show invaluable in planning the development of rural and urban settlements. Among other things, such studies help in the formulation of strategies for improving the quality of life for the identification of problem areas within the village or town, discovering the causes of discontent among the population, learn the with citizens' priorities, monitoring and evaluation of the impact of political ideas and strategies across a number of indicators of quality of life.

According to Dymitrow and Brauer (2014) including and research Dymitrow (2013), Tunbridge, and Ashworth (1996), Kirshenblatt - Gimblett (1998) and Ashworth (2007) emphasize that firstly, the quality of whose life is implied when applied onto a rural development strategy? If we agree to adopt a more humanistic paradigm to development, but still consider the need for a rural development policy, does it mean that the lives of rural people are attributed some special qualities? Moreover, who are those rural people in light of the immense difficulties to define both 'rurality' and 'locality' as a result of the rural-urban blurring? And who should decide who 'rural people' are and what is considered best for them? Secondly, using the highly contested concept of heritage as a central measure of monitoring QOL seems questionable in the face of the large body of criticaltheoretical work on the subject. Thirdly, despite being a timely and seemingly important concept, QOL straddles many conceptual boundaries - economic, material, psychological, moral, and so forth.

In recent years according to Oktay $\left(^{* *}\right)$, a number of cities have developed indicator programmers aimed at tracking their progress toward becoming more sustainable and livable. At the same time, programmers have been launched in several cities that aim at measuring the quality of life and more specifically, quality of urban life. These programmers have used either a series of objective measures to assess quality of life or resident surveys that tap the attitudes and behaviors of citizens. As highlighted by Marans (2007), "seldom have both types of measures been employed. Typically the programmers have been designed to inform policy decisions of local governmental, corporate, and non-profit organizations. Yet few programmers have been guided by theories emanating from academia". There are two critical issues facing those operating in the context of the public policy and planning for urban areas and social sciences. One deals with the meaning and 
measurement of quality of life. The other deals with the identification and use of measures or indicators to assess changes in the quality of community life (Oktay, ${ }^{* * *}$ ).

Finally "evaluating life satisfaction in general, lifting up (material) well-being and personal happiness are among the basic and central belief that every human during of life build. In addition to the impact they have on the personal life of the new general life attitudes largely determine the social behavior of people "(Vasović, 2003).

\section{References}

1. Diogenész, L., (2005), Híres filozófusok élete, Budapest: Jel Kiadó.

2. Ilić, I., Milić, I., Aranđelović, M., (2010), Assessing quality of life: Current approaches, Acta Medica Medianae, 49(4),52-60.

3. Vittersø, J., (2004), Subjective Well-Being Versus Self-Actuali-zation: Using the Flow Simplex to Promote a Conceptual Clarification of Subjective Quality of Life, Soc Indic Res., 65(3), 299-332

4. Butow, P., (2009), Quality of life Research in Clinical Trials, C eMPED. Sydney.

5. Milivojević, J., Kokić - Arsić, A., Kanjevac Milovanović, K., Savović, I., Tonić, N., (2012), Life satisfaction - key aspects, 39 National Conference on Quality and 7 National Conference on quality of life, Quality Festival, B $49-$ B 58, Kragujevac.

6. Milivojević, J., Đorđević, J., Stojanović, S.,(2015), Model of sustainable quality of life, 10 National Conference on quality of life, Quality Festival, B 73 - B 88, Kragujevac.

7. Schalock, R. L. (2004). The concept of quality of life: what we know and do not know, Journal of intellectual disability research, 48(3), 203-216.

8. Andráško, I., (2009), The role and status of geography in the quality of life research, Liberec: Technická univerzita, 21, o - 215.

9. Pacone, M., (2003), Urban environmental quality and human wellbeing - a social geographical perspective, Landscape and Urban Planning, 65, 19-30.

10. Andraško, I., (2005), Dve dimenzie kvality života v kontexte percepcií obyvatel'ov miesta vidieckych obcí, In: Vaishar, A., Ira, V. (eds.): Geografická organizace Česka a Slovenska v současném období. Ústav geoniky Akademie věd ČR, Brno, pp. 6-13.

11. Andraško, I., (2006), Percepcia kvality života v mestských štvrtiach Bratislavy, Geografická revue, 2, 227-240.

12. Andraško, I., (2007), Vnútorná štruktúra mesta z hl'adiska kvality života, Dizertačná práca, Geografický ústav SAV, Bratislava.

13. Bohnke, P., (2005), First European quality of life survey: Life satisfaction, happiness and sense of belonging. Luxembourg: European Foundation for the Improvement of Living and Working Conditions, Office for Official Publications of the European Communities.

14. Rajović, G., Bulatović, J., (2012), Socio economic and geographical factors of developmentStudy Case: Cities Berana, Andrijevica and Plava, Journal for Geography, 7(1), 49 - 68,

15. Rajović, G., Bulatović, J., (2013), Analysis of Change in Population Structure: The Case Northeastern Montenegro, Journal of Studies in Social Sciences, 2(1), 1 - 30.

16. Rajović, G., Bulatović, J., (2013), Movement population in the second of XX and beginning of XXI century: The Case northeastern Montenegro, Russian Journal of Agricultural and Socio - Economic Sciences, 1(13), 66-79.

17. Rajović, G., Bulatović, J., (2013), Geographical View on Households: the Case Northeastern Montenegro, Open Journal of Social Science Research, 1(7),169-173.

18. Rajović, G., Bulatović, J., (2015), Demographic Processes and Trends: The Case of Region Polimlje-Ibar, International Letters of Social and Humanistic Sciences, 63, 17-29.

19. Rajović, G., Bulatović, J., (2015), Regional - Demographic Problems and Quality of Life in Northeastern Montenegro: A Case Study, European Geographical Studies, 5(1), 18-33.

20. Rajović, G., Bulatović, J., (2015), Different attitudes toward the quality of life concept, Azerbaijanian Journal of Economics and Social Studies, 4, 70 - 93.

21. Rajović, G., Bulatović, J., (2016), Life Satisfaction - Migrants from Serbia and Montenegro to Denmark: Case Study, European Researcher. Series A, 102 (1), $25-43$.

22. Kajari, K., Šandor, Š., (2011),Comparative analysis of living conditions in settlements of northern Vojvodina, Deturope- the central european journal of regional development and tourism, 3(1),11-33. 
23. Thompson, J. H., Sufrin, S. C., Gould, P. R., Buck, M. A., (1962), Toward a geography of economic health: the case of New York state, Annals of the Association of American Geographers, $52,1-20$.

24. Lewis, G. M., (1968), Levels of Living in the North-Eastern United States c. 1960: A New Approach to Regional Geography, Transactions of the Institute of British Geographers, 45, 11-37.

25. Bunge, W., (1973), The geography of human survival, Annals of the Association of American Geographers, 63, 275-295.

26. Smith, D., (1973), An introduction to welfare geography, Department of Geography and Environmental Studies, Johannesburg, University of the Witwatersrand.

27. Knox, P. L., MacLaran, A., (1978), Values and perceptions in descriptive approaches to urban social geography, in: D. Herbert and R. Johnston, (Ed.), Geography and the Urban Environment, John Wiley, Chichester, Sussex, 197-247.

28. Frazier, J. W., (1982), Applied Geography: A Perspective, In: Frazier, J. W. (ed.): Applied Geography: Selected Perspectives. Prentice-Hall, Englewood Cliffs.

29. Helburn, N., (1982), Presidential address: Geography and the Quality of Life, Annals of the Association of the American Geographers, 72(4), 445-456.

30. Sufian, A. J. M., (1993), A multivariate analysis of the determinants of urban quality of life in the world 's largest metropolitan areas, Urban Studies, 30, 1319-1329.

31. Oliver, N., Holloway, F., Carson, J. (1995.): Deconstructing quality of life, Journal of Mental Health, 4, 1-4.

32. Johnston, J., (1997), Geography and geographers: Anglo-American human geography since 1945, Arnold London.

33. Diener, E., Suh, E., (1997), Measuring quality of life: Economic, social, and subjective indicators, Social Indicators Research, 40, 189-216.

34. Diener, E., Suh, E. M., Lucas, R. E., Smith, H., (1999), Subjective well being: Three decades of progress, Psychological Bulletin, 125, 276-302

35. Hagerty, M.R., Cummins R.A., Ferriss A.L, Land, K., Michalos, A., Peterson, M., Sharpe, A., Sirgy, M.J., Vogel, J., (2001), Quality of Life Indexes for National Policy: Review and Agenda for Research, Social Indicators Research, 55(1),1-96.

36. Massam, B.H., (2002), Quality of life: public planning and private living, Progress in Planning,58,141-227.

37. Scollon, C. N., Kim-Prieto, C. i Diener, E. (2003.): Experience sampling: Promises and pitfalls, strengths and weaknesses, Journal of Happiness Studies, 4, 5-34.

38. KaÚeman, D. i Krueger, A. B. (2006), Developments in the Measurement of Subjective Well-Being, Journal of Economic Perspectives, 20 (1), 3-24.

39. Ira, V., Andraško I., (2007), Kvalita života z pohl'adu humánnej geografie, Geografický časopis, 59, 159-179.

40. Heady, B. (2008.): Life goals matter to happiness: a revision of set point theory, Social indicators research, 86, 213-231.

41. Brereton, F., Clinch, J.P., Ferreira, S., (2008), Happiness, geography and the environment, Ecological economics, 65, 386-396.

42. Slavuj, L., (2012), Objective and subjective indicators in the research of the concept of quality of life, Geoadria, 17(1), 73-92.

43. Rajović, G., Bulatović, J., (2016), Life as a geographical theme - one more contribution to the study of quality of life, World Scientific News,28,41-57.

44. Rajović, G., Bulatović, J., (2016), Theorecital approach to the study of quality of life in rural and urban settlements, Annals of the University of Oradea - Geography Series, XXVI (1), 5 - 24.

45. Arsovski, S., Stojković, D., (2014), Qality of life on rural communities, 41 National Conference on Quality and 9 National Conference on quality of life, Quality Festival, pp. 34-1 34 -7, Kragujevac.

46. Rapley, M., (2003), Quality of life research: a critical introduction, Sage, London.

47. Massam, B.H., (2002), Quality of life: public planning and private living, Progress in Planning, 58(3), 141-227.

48. Myers, D., (1988), Building knowledge about quality of life for urban planning, Journal of the American Association of Planners, 54, 347-358. 
49. Baycan Levent, T., Nijkamp, P., (2006), Quality of Urban Life: A Taxonomic Perspective, Studies in Regional Science, 36(2), 269-281.

50. Milivojević, J., Kokić Arsić, A., Kanjevac Milovanović, K., (2006), Troght indicators to better quality of life, 1 National Conference on quality of life, Quality Festival May 10 to 12, pp. B 21-B25, Association for Quality and Standardization of Serbia, Kragujevac.

51. Slavuj, L., (2014), Problem of determining the complex (objective and subjective) index as a comprehensive measure of the quality of life, Sociologija i prostor, 52 (1 (198)), 23-39.

52. Eyles, J., (1994), Social Indicators, Social Justice and Social Well-being, Centre for Health Economics and Policy Analysis (CHEPA), McMaster University, Hamilton, Canada.

53. Wong, C., (2006), Indicators for Urban and Regional Planning, London: Routledge.

54. Malkina-Pykh, I. G., Pykh, Y. A., (2008), Quality-of-life indicators at different scales: Theoretical background, Ecological Indicators, 8 (6), 854-862.

55. Dzurova, D., Dragomirecka, E., (2000), Quality of life in the Czech Republic, Acta Universitatis Carolinae Geographica, 1, 103-116.

56. Trauer, T., Mackinnon, A., (2001), Why are we weighting? The role of importance ratings in quality of life measurement, Quality of Life Research: An International Journal of Quality of Life Aspects of Treatment, Care and Rehabilitation, 10 (7), 579-585.

57. Alcazar, L., Andrade, R., (2008), Quality of life in urban neighborhoods in Metropolitan Lima, Peru, Inter-American Development Bank, Research Department.

58. Experts Group on Health Information (2013), Eurostat, Available from: http://epp.eurostat.ec.europa.eu (22.10 2015).

59. Eurostat- European Commission (2014), Available from: http://epp.eurostat.ec. europa.eu (23.10 2015).

6o. Kuz, T., (1978), Quality of life, an objective and subjective variable analysis, Regional Studies 12 (4), 409-417.

61. Omuta, G. E. D., (1988), The Quality of Urban Life and the Perception of Livability: A Case Study of Neighbourhoods in Benin City, Nigeria, Social Indicators Research 20 (4), 417-440.

62. Tuan Seik, F., (2000), Subjective assessment of urban quality of life in Singapore (19971998), Habitat International 24 (1), 31-49.

63. Santos, L., Martins, I., (2007), Monitoring Urban Quality of Life: The Porto Experience, Social Indicators Research 80 (2), 411-425.

64. Priego, C., Breuste, J. H., Rojas, J., (2008), Perception and value of nature in urban landscapes: a comparative analysis of cities in Germany, Chile and Spain, Landscape Online, (7).

65. Feneri, A. M., Vagiona, D., Karanikolas, N., (2013), Measuring Quality Of Life (Qol) In Urban Environment: An Integrated Approach, Cest2013, Athens, Greece.

66. Rezvani, M. R., Mansourian, H., Sattari, M. H., (2013), Evaluating quality of life in urban areas (case study: Noorabad City, Iran), Social indicators research, 112(1), 203-220.

67. Rosu, L., Corodescu, E., Blageanu, A., (2015), Does geographical location matter ?Assessing spatial patterns in perceived quality of life in European cities, European Journal of Geography,2,15-34.

68. Ryff Carol, D., Magee William, J., Kling Kristen, C., Wing Edward, H., (1999), Forging macro-micro linkages in the study of psychological well-being, in: C. D. Ryff and V. Marshall (ed.), The Self and Society in an Aging Process. New York: Springer, pp. 247-278.

69. Kling, K. C., Wing E. H., (1999), Forging Macro-Micro Linkages in the Study of Psychological Well-Being, The Self and Society in Aging Processes, 247.

70. Nezlek, J. B., (2000), The motivational and cognitive dynamics of day-to-day social life, The social mind: Cognitive and motivational aspects of interpersonal behavior, 92-111.

71. Markus, H. R., Ryff, C. D., Curhan, K. B., Palmersheim, K. A., (2004), In their own words: Well-being at midlife among high school-educated and college-educated adults, How healthy are we, 273-319.

72. Ryan, R. M., Huta, V., (2009), Wellness as healthy functioning or wellness as happiness: The importance of eudemonic thinking (response to the Kashdan et al. and Waterman discussion), The Journal of Positive Psychology, 4(3), 202-204.

73. Diaz - Serrano, L., Cabral Vieira, J.A., (2005), Low pay, higher pay and job satisfaction within the European Union: Empirical evidence from fourteen countries, IZA Discussion Papers, Institute for the Study of Labour. 
74. Rajović, G., Bulatović, J., (2015), Structural Changes in Livestock Production in Montenegro (2004-2012): A Review, European Geographical Studies, 7(3), 128-136.

75. Ross, C.E., Reskin, B.F., (1992), Education, control at work, and job satisfaction, Social Science Research, 21, 134-148.

76. Spector, B., (1995), The sequential path to transformation management, European Management Journal, 13 (4), 382-389

77. Clark, A.E., (1996), Job satisfaction in Britain, British Journal of Industrial Relations, 34, 189-217.

78. Gazioglu, S., Tansel, A.,(2006), Job satisfaction in Britain: Individual and job related factors, Applied Economics, 38, 1163-1171.

79. Fabra, E.B., Camisón, C., (2009), Direct and indirect effects of education on job satisfaction: A structural equation model for the Spanish case, Economics of Education Review, 28, $600-610$.

8o. Olds in Montenegro live almost the poorly in the world, Available from: http://vijesti.me (24.10 2015).

81. Svirčić Gotovac, A., (2006), The quality of housing in the settlements network in Croatian, Sociologija i prostor, 44, 171 (1), 105-126.

82. Bokić,J.,Čikić,J...,($\left.{ }^{* * *}\right)$, The quality of life in rural settlements, Available from: http://www.doiserbia.nb.rs (15.10 2015).

83. Knight, M., Stewart-Brown, S., Fletcher, L.,(2001), Estimating health needs: the impact of a checklist of conditions and quality of life measurement on health information derived from community surveys, Journal of Public Health, 23(3), 179-186.

84. Alonso, J., Ferrer, M., Gandek, B., Ware Jr, J. E., Aaronson, N. K., Mosconi, P., ... Leplège, A., (2004), Health-related quality of life associated with chronic conditions in eight countries: results from the International Quality of Life Assessment (IQOLA) Project, Quality of life research, 13(2), 283-298.

85. Efklides, A., Varsami, M., Mitadi, I., Economidis, D., (2006), Health condition and quality of life in older adults: Adaptation of qolie-89, Social indicators research, 76(1), 35-53.

86. Trgovčević, S., Milićević, M., Nedović, G., Jovanić, G., (2014), Health Condition and Quality of Life in Persons with Spinal Cord Injury, Iranian Journal of Public Health, 43(9), 12291238.

87. Mirković, M., Simić, S., (2011), Predictors of self-rated health of citizens on the territory of endangered political security, Medicinski pregled, 64(3-4), 168-172.

88. Okosun, I.S., Choi, S., Matamoros, T., Dever, G.E., (2001), Obesity is associated with reduced self-rated general health status: evidence from a representative sample of white, black, and Hispanic Americans, Prev Med., 32, 429-36.

89. Bath, P.A., (2003), Differences between older men and women in the self-rated health: mortality relationship, Gerontologist, 43, 387-95.

90. Bond, J., Dickinson, H.O., Matthews, F., Jagger, C., Brayne, C.,(2006), Self-rated health status as a predictor of death, functional and cognitive impairment: a longitudinal cohort study, Eur J Ageing, 3, 193-206.

91. Ford, J., Spallek, M., Dobson, A., (2008), Self-rated health and a heal thy lifestyle are the most important predictors of survival in elderly women, Age Ageing, 37, 194-200.

92. Norekval, T.M., Fridlund, B., Rokne, B., Segadal, L., Wentzel-Larsen, T., Nordrehaug, J.E., (2010), Patient-reported outcomes as predictors of 10-year survival in women after acute myocardial infarction, Health Qual Life Outcomes, 8(1), 140-4.

93. Idler, E.L., Benyamini, Y., (1997), Self-rated health and mortality: a review of twentyseven community studies, $J$ Health Soc Behav., 38, 21-37.

94. Idler, E.L., Hudson, S.V., Leventhal, H., (1999), The meanings of self-ratings of health. a qualitative and quantitative approach, Res Aging, 21, 458-76.

95. Mansson, N.O., Rastam, L., (2001), Self-rated health as a predictor of disability pension and death: a prospective study of middle-aged men, Scand J Public Health, 29, 151-8

96. Kaplan, G., Baron-Epel, O., (2003), What lies behind the subjective evaluation of health status? Soc Sci Med , 56,1669-76. 
97. Menec, V.H., Chipperfield, J.G., (2001), A prospective analysis of the relation between self-rated health and health care use among elderly Canadians, Can J Aging, 20, 293-306.

98. DeSalvo, K.B., Fan, V.S., McDonell, M., Stephan, F.,(2005), Predicting mortality and health care utilization with a single question, Health Serv Res, 40, 1234-46.

99. Phillips, L.J., Hammock, R.L., Blanton, J.M., (2005), Predictors of self-rated health status among Texas residents, Prev Chronic Dis (serial online) 2005 Oct (date cited,) Available from: http://www.cdc.gov (18.10 2015).

100.Sabbah, I., Drouby, N., Sabbah, S., Retel-Rude, N., Mercier, M., (2003), Quality of life in rural and urban populations in Lebanon using SF-36 health survey. Health and quality of life outcomes, 1(1), 30.

101. Oguzturk, O., (2008), Differences in quality of life in rural and urban populations, Clinical \& Investigative Medicine, 31(6), 346-350.

102. Carta, M. G., Aguglia, E., Caraci, F., Dell'Osso, L., Di Sciascio, G., Drago, F., ... Balestrieri, M., (2012), Quality of life and urban/rural living: preliminary results of a community survey in Italy, Clinical practice and epidemiology in mental health, $C P \& E M H, 8,169$.

103. Dos Santos Tavares, D. M., Fernandes Bolina, A., Aparecida Dias, F., dos Santos Ferreira, P. C., José Haas, V., (2014), Quality of life of elderly, Comparison between urban and rural areas, Investigación y Educación en Enfermería, 32 (3), 401-413.

104.Marans, R., Rodgers, W., (1975), Toward an understanding of community satisfaction, in: A. Hawley Amos and Rock Vincent (Eds.) Metropolitan America in Contemporary Perspective, New York: Halsted Press.

105. Campbell, A. Converse, P. E., Rodgers, W. L., (1976), The quality of American life: perceptions, evaluations and satisfactions, New York: Russell Sage Foundation.

106.Wellman, B., Wortley, S., (1990), Different Strokes from Different Folks: Community Ties and Social Support, The American Journal of Sociology, 96 (3), 558-588.

107.Lu, M., (1999), Determinants of Residential Satisfaction: Ordered Logit vs. Regression

Models, Growth and Change, 30 (2), 264-287.

108.Parkes, A., Kearns, A., Atkinson, R., (2002), What Makes People Dissatisfied with their

Neighbourhoods?, Urban Studies, 39 (13), 2413-2438.

109.Lovejoy, K. Handy, S., Mokhtarian, P., (2010), Neighborhood satisfaction in suburban versus traditional environments: An evaluation of contributing characteristics in eight California neighborhoods, Landscape and Urban Planning, 97 (1), 37-48.

110. Bogadi Klempić,S., Podgorelec, S., Šabijan, M.,(2011),_Croatian village at the beginning of the 21st century - studies case of Upper Rijeka, Sociologija i prostor,53, 202(2),139-161.

111. Rajović,G.,Bulatović,J.,(2015), Traffic Infrastructure as Precondition Development Tourism on the Mountain Katuns: Example of Municipality Andrijevica, European Journal of Social and Human Sciences, 7(3), 150-162.

112. Slavuj, L., (2012), Evaluation of the quality of urban neighborhoods - the advantages and disadvantages of the immediate living space, Sociologija i prostor, 50 (2 (193)), 183-201.

113. Li, G., Weng, Q., (2007), Measuring the quality of life in city of Indianapolis by integration of remote sensing and census dana, International Journal of Remote Sensing, 28 (2), 249-267.

114. Dymitrow, M., Brauer, R., (2014), Quality of life in rural areas: A topic for the Rural Development policy?, Bulletin of Geography. Socio - economic Series, (25), 25-54.

115. Dymitrow, M., (2013), Degraded towns in Poland as cultural heritage, International Journal of Heritage Studies, 19(7), 613-631.

116. Tunbridge, J.E., Ashworth, G.J., (1996), Dissonant heritage: the management of the past as a resource in conflict, London: Wiley.

117. Kirshenblatt - Gimblett, B., (1998), Destination Culture: Tourism, Museums, and Heritage. Berkeley: University of California Press.

118. Ashworth, G.J., (2007), On townscapes, heritages and identities, In: IAS Annual Research Programme 2006-07 'Regions and Regionalism in and beyond Europe'; Colloquium 3: Urban-rural: Flows and Boundaries; Session 2 - Townscapes and Landscapes, 9-10 January 2007, Lancaster: Lancaster University. 
119. Oktay, D., $\left(^{* * *}\right)$, Quality of Urban Life Studies for Sustainability and Livability: A Research Framework for Gazimagusa (Famagusta), In ICANAS 38 (International Congress on Asian and North African Studies).

120.Marans, R., (2007), Quality of Life Studies and their Contributions to Housing and Policy”, Gazimagusa Municipality Seminars, 26 March Gazimagusa.

121. Vasović, V., (2003), Transition, democratization and "personal welfare", Sociološki pregled, 37(1-2) (2003) 3-32.

\title{
УДК 33
}

\section{Сравнительный анализ условий жизни в населенных пунктах муниципалитета Беране и поселений муниципалитета Андриевица: тематическое исследование}

\author{
${ }^{1}$ Горан Ройович \\ 2 Джелисавка Булатович
}

${ }^{1}$ Международный сетевой центр фундаментальных и прикладных исследований, Российская Федерация

Член научного общества ATINER, Сербия

Доктор

E-mail: dkgoran.rajovic@gmail.com

${ }^{2}$ Колледж текстильного дизайна, технологии и управления, Сербия

Улица Старне Новака, 24, Белград

Магистр

E-mail: jelisavka.bulatovic@gmail.com

Аннотация. Статья базируется на исследовании вопросов качества жизни, которые в последнее время становятся все более важной социально-экономической проблемой. В работе обсуждается, каким образом в контексте качества сельской жизни предоставляется возможность для разрешения парадокса развития, рассматриваемым многими исследователями. Исследование было разработано и проведено в географическом и социальном пространстве, в качестве примера. В географическое пространство исследования включены городские поселения: Беране и Андриевица, а также сельские: Долац, Lužac, Dapsiće, Луге, Полица, Gnjili Potok, Kralje, Слатина, Zabrđe и Риека Marsenić. Социальное пространство охватывает опрошенных жителей, что означает, и наше понимание социальной среды. Существование различий в условиях жизни, возможностей и отношений городских и сельских жителей были сформулирована в качестве гипотезы в исследовании. Цель исследования заключается в том, что сравнительный обзор условий труда и быта сельского и городского населения и сравнительный анализ данных проверил правильность первоначального предположения. Анализ включает в себя следующие зависимые переменные: уровень образования, род занятий, жилищные условия, состояние здоровья, удовлетворенность пациентов и ранжирование причин для беспокойства респондентов, живущих в городе, является независимой переменной.

Ключевые слова: условия жизни, сельские, городские, муниципалитет Berane, муниципалитет Andrijevica, исследования. 